\title{
ДИПЛОМАТИЧЕСКОЕ ПРАВО
}

\section{КОНСУЛЬСКИЕ КОНВЕНЦИИ АЗЕРБАЙДЖАНСКОЙ РЕСПУБЛИКИ С ИНОСТРАННЫМИ ГОСУДАРСТВАМИ И ВЕНСКАЯ КОНВЕНЦИЯ КОНСУЛЬСКИХ СНОШЕНИЙ 1963 г. (сравнительный анализ основных положений)}

Аскеров $A$ *

После провозглашения Азербайджанской Республикой своей независимости и вслед за признанием ее мировым сообществом последовало установление дипломатических отношений с зарубежными странами, что автоматически предполагало и установление консульских отношений, началась работа по аккредитации дипломатических представительств в иностранных государствах, соответственно и иностранных посольств и консульств на территории Азербайджанской Республики. Так, в числе первых генеральные консульства Турции, Ирана и Ирака, действовавшие еще в советское время, преобразовались в посольства этих государств в Азербайджанской Республике. Преобразовалось также в Посольство Азербайджанской Республики в Российской Федерации функционировавшее в бывшем Советском Союзе Постоянное представительство Совета Министров Азербайджанской ССР при Совете Министров СССР. Открылось и Посольство Российской Федерации в Баку и т.д.

Естественно, возникла необходимость в участии Азербайджанской Республики в таких международных договорах, как Венская конвен-

\footnotetext{
• Аскеров Алимирзамин - начальник Управления по правам человека, демократизации и гуманитарных проблем МИД Азербайджанской Республики.
} 
ция о дипломатических сношениях 1961 г. и Венская конвенция о консульских сношениях 1963 г., которые соответственно регулируют эти отношения между государствами.

С выходом на международную арену в качестве суверенного государства Азербайджанская Республика сразу начала работу по присоединению к авторитетным международным документам. В числе первых следует назвать, в частности, Венскую конвенцию о консульских сношениях 1963 г., к которой Азербайджанская Республика присоединилась в 1992 г.

Положения Венской конвенции не препятствуют государствам заключать международные соглашения, подтверждающие, дополняющие, распространяюшие или расширяющие ее положения.

С 1992 г. по настояшее время Азербайджанская Республика заключила десять консульских конвенций: с Турецкой Республикой - 1992 г,, Египтом - 1994 г., Китайской Народной Республикой (КНР) - 1994 г,, Российской Федерацией - 1995 г., Туркменистаном - 1996 г., Казахстаном - 1996 г., Пакистаном - 1996 г., Грузией - 1996 г., Украиной 1996 г. и Узбекистаном - 2004 г.

В соответствии с современным международным правом консульскими конвенциями являются соглашения, которые содержат нормы консульского права, определяющие порядок учреждения консульских представительств, назначения и отозвания, круг деятельности, права, привилегии и иммунитеты консульских должностных лиц и сотрудников консульства. ${ }^{1}$

Двусторонние консульские конвенции - это международные соглашения, направленные на урегулирование и развитие консульских отношений между двумя государствами с целью более эффективной защиты прав и интересов своих граждан и юридических лиц, а также на содействие развитию и укреплению двусторонних дружественных связей и взаимовыгодного сотрудничества в различных областях. Они содержат нормы консульского права, определяющие открытие консульских учреждений на взаимной основе, назначение и допущение глав этих учреждений, функции, привилегии и иммунитеты консульских учреждений и должностных лиц.

Все анализируемые конвенции заключены на неопределенный срок и могут быть в любое время денонсированы, «если одна из Договаривающихся Сторон по дипломатическим каналам представит другой

\footnotetext{
' Словарь международного права. М.: Межд. отношения, 1986. С. 134.
} 
Договаривающейся Стороне письменное уведомление о своем намерении прекратить действие настоящей Конвенции...». Такая формулировка записана в заключительных положениях всех рассматриваемых конвенций.

Заключенные Азербайджанской Республикой (АР) консульские конвенции имеют различный объем (количество статей), но структура их (за некоторыми исключениями) в целом сходна. Как правило, они состоят из: преамбулы; определений; порядка открытий консульских учреждений; назначения и допущения глав консульских учреждений; привилегий и иммунитетов (прав, льгот и преимуществ); консульских функций; уважения законов и правил государства пребывания; заключительных положений.

Каждый договорно-правовой акт имеет свои особенности: встречаются иногда статьи, которые не повторяются ни в одном из других актов; некоторые из них имеют четкое разделение на разделы (например, конвенции АР с КНР, Украиной, Турецкой Республикой, Пакистаном), в других конвенциях статьи идут подряд без указания разделов, хотя сгруппированы по вышеуказанным разделам. В одних конвенция сначала перечисляются и раскрываются статьи, посвяшенные консуліьским функциям, а затем привилегиям и иммунитетам, в других, наоборот - сначала указываются привилегии и иммунитеты, а затем консульские функции. Есть разница как в количестве и подробностях функций, так и в числе и объеме привилегий и иммунитетов.

В дальнейшем изложении нам представляется целесообразным, ориентируясь на положения Венской конвенции о консульских сношениях 1963 г., провести сравнительный анализ основных положений вышеназванных конвенций, имея в виду, что все упоминаемые в тексте государства являются участниками Венской конвенции о консульских сношениях 1963 г.

Оставляя в стороне преамбулу Венской конвенции (она достаточно известна), остановимся на изложении и сравнении преамбул рассматриваемых конвенций.

В преамбулах конвенций АР с РФ и Туркменистаном стороны имеют целью «содействовать развитию дружественных отношений между двумя странами, а также более эффективной защите прав и интересов своих граждан, желая установить дополнительные положения для ведения консульских отношений в развитие Венской конвенции о консульских сношениях 1963 г.». 
Большинство других конвенций указывает на желание «дальнейшего укрепления дружественных отношений и сотрудничества между обоими государствами» и “ стремление развивать свои консульские отношения, содействовать защите прав и интересов обоих государств, а также их граждан...».

Конвенция АР с Украиной имеет более развернутое положение преамбулы, указывая на то, что «Договариваюшиеся Стороны, руководствуясь желанием развивать консульские отношения с целью более эффективной защиты прав и интересов обоих государств, их граждан и юридических лиц, укреплением дружбы и сотрудничества между Договаривающимися Сторонами, в развитие Венской конвенции о консульских сношений 1963 г., подтверждая, что по вопросам, которые не оговорены в настоящей Конвенции, будут применяться нормы международного обычного права и многосторонних обычных договоров, участниками которых являются договаривающиеся Стороны...».

Преамбула конвенции АР с КНР выражает общий характер консульских конвенций, заключенных АР с иностранными государствами, отмечая, что заключение этих актов осуществляется «в интересах дальнейшего укрепления дружественных отношений и сотрудничества между обоими государствами, оно должно содействовать защите прав и интересов обоих государств, а также их граждан...». Преамбула конвенции АР с Турецкой Республикой более лаконична, стороны решили заключить консульскую конвенцию, «руководимые желанием и дальше развивать дружественные отношения, а также урегулировать консульские отношения между обеими странами...».

Все конвенции начинаются со ст. 1 «Определения»; в некоторых конвенциях эта статья выделена в отдельный раздел I (например, конвенции AР с Китайской Народной Республикой, Украиной, Турецкой Республикой, Пакистаном), в остальных это просто порядковая статья. В ней раскрываются значения основных терминов, употребляемых в конвенциях, в частности таких как «консульское учреждение», «консульский округ», «глава консульского учреждения», «консульское должностное лицо», «консульские архивы и документы» и др. В целом эта ст. 1 двусторонних конвенций АР в той или иной мере воспроизводит ст. 1 Венской конвенции о консульских сношениях 1963 г. Следует, однако отметить, что некоторые конвенции АР (например, с КНР, Украиной, Турецкой Республикой, Пакистаном) включили в число терминов такие понятия, как «гражданин», «гражданин представляемого государства», «юридическое лицо» и др. 
Статья 2 всех рассматриваемых конвенций посвящена открытию консульских учреждений. В ней подчеркивается, что консульские учреждения представляемого государства открываются на территории государства пребывания только с согласия этого государства. В этой же статье указываются местонахождение консульского учреждения, его класс и консульский округ (в некоторых конвенциях говорится и о численности консульских должностных лиц (конвенции АР с РФ, Туркменистаном, Республикой Узбекистан). Любые изменения в этом отношении могут осуществляться или определяться только по соглашению (договоренности) между представляемым государством и государством пребывания.

Положения ст. 2 двусторонних конвенций АР с иностранными государствами практически полностью совпадают с положениями ст. 4 Венской конвенции о консульских сношениях 1963 г. (правда, некоторые ее дают в сокращении (ст. 2 конвенции АР с Украиной), другие дают в расширительном виде (ст. 2 конвенции АР с Турецкой Республикой).

Далее все конвенции уделяют внимание рассмотрению вопроса о назначении и допущении глав консульских учреждений.

Во всех рассматриваемых конвенциях говорится, что допушение глав консульских учреждений осуществляется после получения предварительного согласия (предварительного согласования с принимаюшей стороной) на назначение данного лица главой консульского учреждения (генеральным консулом, консулом, вице-консулом, консульским агентом). То есть требуется своего рода агреман, сближающий положение консула с положением посла как руководителей загранпредставительств. В этой связи следует заметить, что термин «агреман» как получение предварительного согласия на назначение главы консульского учреждения в настоящее время в консульской практике не используется, однако в научной литературе советского периода он присутствовал. ${ }^{2}$ Назначение главы консульского учреждения, как и главы дипломатического представительства в каждом государстве, осуществляется в соответствии с внутренним законодательством посылающего государства.

Следующим этапом в допущении консула к своим обязанностям следует представление главой консульского учреждения (по дипломатическим каналам) патента направляющего государства. Относитель-

${ }^{2}$ Дурденевский В.Н. Консульские конвенция и договоры Союза ССР 1955-1959 гт. // Советский ежегодник международного права. 1961. М.: АН СССР, 1962. С. 135. 
но консульского патента, то есть документа, подтверждающего полномочия лица о его назначении главой консульского учреждения, конвенция АР с РФ устанавливает требования, чтобы в патенте были указаны полное имя, фамилия главы консульского учреждения, его гражданство, класс (ранг), консульский округ и местонахождение консульского учреждения; в конвенциях АР с КНР и Туркменистаном содержатся аналогичные требования к содержанию патента (помимо упоминания о гражданстве); в конвенции АР с Украиной никаких критериев требований, к главе консульского учреждения не содержится (ст. 3 этой конвенции просто указывает, что представляемое государство передает МИДу государства пребывания консульский патент или уведомление о назначении данного лица главой консульского учреждения, без раскрытия содержания документа). Таким образом, в рассматриваемых конвенциях гражданство главы консульского учреждения не упоминается (за исключением конвенции с РФ). Однако в статьях указанных конвенций о гражданстве консульских должностных лиц, к которым, между прочим, относится и глава консульского учреждения, подчеркивается, что консульские должностные лица должны быть гражданами представляемого государства (ст. 6 конвенций АР с Укранной, Туркменистаном, КНР, Узбекистаном, РФ, Грузией, ст. 3 конвенции с Пакистаном и др.). Из этого следует, что глава консульского учреждения должен быть обязательно гражданином представляемого государства.

После получения от государства пребывания разрешения (называемого экзекватурой) глава консульского учреждения приступает к исполнению своих обязанностей, а государство пребывания обеспечивает принятие мер, необходимых для того, чтобы он: «мог исполнять обязанности по своей должности и пользоваться преимуществами, вытекающими из конвенции» (ст. 3 конвенций АР с РФ и Туркменистаном), «мог выполнять свои функции и пользоваться правами, привилегиями и иммунитетами, предусмотренными конвенцией») (ст. 3 конвенции АР с КНР); «имел возможность выполнять свои обязанности и пользоваться всеми правами, преимуществами, привилегиями и иммунитетами, предусмотренными конвенцией (ст. 3 конвенции. АР с Украиной) и т.д.

Общий смысл всех этих формулировок - обязанность принимающего государства обеспечить главе консульского учреждения полную свободу отправления его функций в соответствии с положениями рас- 
сматриваемых конвенций, Венской конвенции о консульских сношениях 1963 г. и внутреннего законодательства.

К вышеизложенному следует добавить, что во всех анализируемых конвенциях нет классификации глав консульских учреждений, как это зафиксировано в ст. 9 Венской конвенции о консульских сношениях 1963 г.

Видимо, следует исходить из того, что авторы конкретной конвенции принимали во внимание именно эту статью, так как их государства являются членами Венской конвенции о консульских сношениях 1963 г., или руководствовались международным обычаем, который эту классификацию уже давно применял.

Исходя из вышеизложенного, можно сделать вывод, что деятельность главы консульского учреждения начинается с даты получения согласия (экзекватуры) от властей государства пребывания на выполнение им своих полномочий.

Во всех рассматриваемых консульских конвенциях указывается (как правило, в ст. 3), что до выдачи экзекватуры глава консульского учреждения может быть временно допущен к выполнению своих функций. Это положение полностью соответствует ст. 13 Венской конвенции 1963 г., которая так и называется «Временное допущение глав консульских учреждений». Правда, следует заметить, что как в ст. 3 двусторонних консульских конвенций АР, так и в ст. 13 Венской конвенции не упоминаются подробности разрешения на временное допущение, но можно предположить, что такое допущение (форма, время и др.) дается теми же органами власти, которые выдают экзекватуру, и оно имеет, по всей видимости, письменную форму.

Таковы вопросы, связанные с началом миссии главы консульского учреждения.

Венская конвенция о консульских сношениях в ст. 23, 25-27 предусматривает случаи прекрашения деятельности главы консульского учреждения. В соответствии с этими статьями консульские функции прекращаются:

1) в случае объявления главы консульского учреждения persona non grata;

2) по уведомлению представляемым государством государства пребывания о том, что его функции прекращаются;

3) по аннулировании экзекватуры государством пребывания;

4) в случае разрыва консульских отношений между представляемым государством и государством пребывания. 
Практически все конвенции АР с иностранными государствами воспроизводят почти дословно вышеуказанные положения Венской конвенции 1963 г. (см. ст. 7, 51, 53 конвенций АР с РФ, Туркменистаном, Грузией; ст. 8, 51, 53 конвенции с Украиной; ст. 7, 49, 51 - с Республикой Узбекистан; ст. 9 - с Турецкой Республикой и Пакистаном и т.д.).

Международной консульской практике известны следующие случаи прекращения миссии главы консульского учреждения:

1) отозвание консула представляемым государством;

2) аннулирование экзекватуры консула государством пребывания;

3)истечение срока консульского патента (в последнее время этот срок в консульских конвенциях не указывается);

4)закрытие консульского учреждения в данном пункте;

5)прекрашение консульских отношений между представляемым государством и государством пребывания;

6)война или военный конфликт между государством пребывания и представляемым государством;

7)выход территории, где находится консульский округ, из-под суверенитета государства пребывания или представляемого государства;

8)смерть консула. ${ }^{3}$

Касаясь вопроса назначения работников консульского персонала, следует отметить, что все рассматриваемые конвенции (как правило в ст. 5) предоставляют право представляемому государству свободно назначать должностных лиц и других работников консульского персонала, обязывая его при этом заблаговременно сообщать государству пребывания полное имя и фамилию, категорию и класс всех консульских должностных лиц или работников консульского учреждения.

Вместе с тем все конвенции предусматривают право государства пребывания (как правило, в ст. 7) уведомить представляемое государство по дипломатическим каналам, что то или иное консульское должностное лицо является percona non grata или что любой работник консульского персонала является неприемлемым. В таком случае представляемое государство должно отозвать это лицо или прекратить его функции в консульском учреждении.

Положения двусторонних консульских конвенций в ст. 5 и 7 фактически повторяют дословно содержание соответственно ст. 19 и 23 Венской конвенции о консульских сношениях 1963 r.

\footnotetext{
${ }^{3}$ Международное право / Под ред. В.И. Кузнецова. М.: Юристъ, 2002. С. 454.
} 
К вышеизложенному следует добавить, что анализируемые конвенции не содержат положений, зафиксированных в ст. 20 Венской конвенции 1963 г., которые предоставляют государству пребывания право некоторым образом «регулировать» численность консульского персонала представляемого государства.

В статье 22 Венской конвенции рассматриваются вопросы гражданства консульских должностных лиц. Статья акцентирует внимание на том, что в принципе консульские должностные лица должны быть гражданами представляемого государства (п. 1 ст. 22). Консульские должностные лица не могут назначаться из числа граждан государства пребывания или граждан третьего государства иначе как с определенно выраженного согласия государства пребывания; причем это согласие может быть в любое время аннулировано (п. 2 и 3 ст. 22).

Из этого следует, что Венская конвенция не содержит обязательного правила гражданства аккредитующего государства штатных консульских должностных лиц, в отличие от двусторонних консульских конвенций, в которых это правило подчеркивается. ${ }^{4}$

Консульские конвенции, заключенные Азербайджанской Республикой с иностранными государствами, подчеркивают в ст. 6 (в конвенциях AP с Пакистаном и Турцией эта норма закреплена в ст. 3), что консульские должностные лица должны быть гражданами представляемого государства. При этом консульская конвенция АР с КНР добавляет в соответствующей статье, что этот гражданин не должен быть лицом, постоянно проживающим в государстве пребывания.

В соответствии со ст. 68 Венской конвенции о консульских сношениях каждое государство вправе свободно решать, будет ли оно назначать или принимать почетных консульских должностных лиц.

Большинство анализируемых консульских конвенций содержат статью (как правило, 10), предусматривающую использование в консульских отношениях между участниками конвенций института почетных консулов. В этой статье указывается, что «если обе Договаривающиеся Стороны согласятся на назначение почетного консульского должностного лица, они консультируются друг с другом по вопросу заключения соответствующих соглашений на основе положений настоящей Конвенции и норм обычного международного права в целях определения режима, который будет применяться к почетным консульским дол-

\footnotetext{
${ }^{4}$ Смирнов Ю.М. Консульское право: практика применения. М.: НИМП, 2001. С. 58.
} 
жностным лицам» (конвенции АР с РФ, Грузией, Туркменистаном, Узбекистаном и др.) Консульская конвенция АР с Украиной в ст. 7 определяет, что “ каждая из Договаривающихся Сторон свободна решать, будет ли она назначать и принимать почетных консульских должностных лиц. Вопрос назначения почетного консульского должностного лица, определение его статуса и круга функциональных обязанностей решается Договаривающимися Сторонами дипломатическим путем на основе положений Венской конвенции о консульских сношениях 1963 г. и норм международного обычного права».

Консульские конвенции АР с КНР, Пакистаном и Турцией об использовании института почетного консула не упоминают.

Для успешного выполнения своих функций консульские учреждения и члены консульского персонала наделяются консульскими привилегиями и иммунитетами.

Консульские привилегии и иммунитеты можно определить как совокупность особых льгот, прав и преимушеств, предоставляемых иностранным консульским учреждениям и их консульским должностным лицам в объеме, определяемом нормами договорного и обычного международного права и законодательством государства пребывания.

Термины «привилегии и иммунитеты» как в теории, так и на практике применяются в качестве собирательных понятий, определяющих привилегированное, исключительное положение, с одной стороны, консульских учреждений, а с другой - членов консульского персонала, выполняющих официальные функции от имени своего государства.

Венская конвенция о консульских сношениях 1963 г. подчеркивает, что привилегии и иммунитеты предоставляются не для выгод отдельных лиц, а для обеспечения эффективного осушествления функций консульских учреждений. В соответствии с конвенцией консульские привилегии и иммунитеты подразделяются на две категории: а) привилегии и иммунитеты консульских учреждений в целом как органов государства; б) привилегии и иммунитеты консульских должностных лиц.

Привилегии и иммунитеты консульских учреждений. Важнейшим иммунитетом, благодаря которому достигается нормальная деятельность консульских учреждений, является неприкосновенность их помещений. Принцип неприкосновенности консульских помещений является общепризнанным в международном праве, он закреплен в Венской конвенции 1963 г. и во многих двусторонних консульских конвенциях.

\footnotetext{
${ }^{5}$ Сандровский К.К. Право внешних сношений. Киев: Виша школа, 1986. С. 310.
} 
Неприкосновенность помещений обеспечивается путем выполнения государством пребывания двух обязанностей: 1) недопустимость вступления местных властей в консульские помещения без согласия главы консульского учреждения или дипломатического представительства; 2) принятие всех надлежащих мер для защиты консульских помешений от всяких вторжений, нанесения ущерба и т.п.

При этом Венская конвенция 1963 г. содержит положение о предполагаемом согласии главы консульского учреждения на доступ в консульские помешения представителей властей государства пребывания «в случае пожара или другого стихийного бедствия, требующего безотлагательных мер защиты» (п. 2 ст. 31 ).

Во всех рассматриваемых конвенциях также имеется специальная статья, указывающая на неприкосновенность консульских помещений. В ней подчеркивается, что власти государства пребывания не могут вступать в ту часть консульских помещений, которая используется исключительно для работы консульского учреждения, иначе как с согласия главы консульского учреждения, главы дипломатического представительства представляемого государства или назначенного одним из них лица (т.е. цитируется ч. 1 п. 2 ст. 31 Венской конвенции). И далее эта статья в конвенцияx АР с РФ, Узбекистаном, Грузией, Туркменистаном имеет следующее продолжение: «Если не будет прямого отказа со стороны лиц, упомянутых в настоящем пункте, то в случае пожара или другого стихийного бедствия, требующего безотлагательных мер защиты, власти государства пребывания могут вступать в консульские помещения. Однако властям не разрешается ни в коем случае нарушать принципы неприкосновенности архива консульских помещений, и в особенности изучать или конфисковывать его» (ст. 13 названных конвенций).

В конвенциях АР с Казахстаном, Пакистаном и Турецкой Республикой это положение изложено следуюшим образом: «В случае возникновения пожара или другого стихийного бедствия, требующих принятия немедленных мер..., такое согласие главы консульского учреждения дается в кратчайший срок» (ст. 15 конвенций).

В конвенциях АР с КНР (ст. 29) и Украиной (ст. 30) положение о неприкосновенности консульских помещений сформулировано, как в п. I и 2 ст. 31 Венской конвенции 1963 г., но без «пожарной» оговорки.

Таким образом, статьи консульских конвенций АР с иностранными государствами, касаюшиеся неприкосновенности консульских помешений при «форс-мажорных» обстоятельствах, в принципе отличают- 
ся от ч. 2 п. 2 ст. 31 Венской конвенции, т.к. они требуют так или иначе согласия консула на вступление властей государства пребывания в консульские помещения. ${ }^{6}$

В двусторонних консульских конвенциях АР указывается, что неприкосновенны также консульские архивы и документы в любое время независимо от их местонахождения (ст. 14 конвенций АР с РФ, Узбекистаном, Грузией, Туркменистаном, Казахстаном; ст. 16 с Турцией и Пакистаном; ст. 32 с Украиной). Они неприкосновенны и в тех случаях, когда в силу каких-либо причин не находятся в пределах консульского учреждения. Требование неприкосновенности консульских архивов и документов означает, что они не могут потерять свой иммунитет даже при разрыве дипломатических или консульских отношений между государствами.

В соответствии с рассматриваемыми конвенциями «консульские пгоещения, предметы их обстановки, имущество консульского учреждения, а также его средства передвижения пользуются иммунитетом от любых видов реквизиции в целях государственной обороны или для общественных нужд». Как правило, это положение зафиксировано в последнем пункте статьи о неприкосновенности консульских помещений; в Венской конвенции 1963 г. - это п. 4 ст. 31.

Одним из основополагающих иммунитетов является право на свободное сношение консульского учреждения с правительством, дипломатическим представительством и другими консульскими учреждениями своего государства. В этих целях консульство может пользоваться всеми подходящими средствами, включая дипломатических и консульских курьеров, дипломатические и консульские вализы и закодированные или шифрованные депеши.

Консульская вализа (опечатанный в установленном порядке мешок, сумка, пакет и т.п. консульского курьера) не подлежит ни вскрытию, ни задержанию. Однако в тех случаях, когда компетентные власти государства пребывания имеют серьезные основания полагать, что в вализе содержится что-то другое, кроме корреспонденции, документов и предметов, предназначенных для официального пользования, они могут потребовать, чтобы вализа была вскрыта в их присутствии уполномоченным представителем представляемого государства. В случае отказа выполнить это требование вализа возвращается в место отправления.

\footnotetext{
${ }^{6}$ Подробнее об этом см.: Ганюшкин Б.В. Широта прав консульских учреждений // Московский журнал международного права. 1999. № 2. С. 222-223.
} 
Это положение Венской конвенции о консульских сношениях 1963 г. (п. 3 ст. 35), по существу, нашло дословное отражение в большинстве консульских конвенций АР (в ст. 17 конвенций с Российской Федерацией, Грузией, Туркменистаном, Узбекистаном, Пакистаном, Казахстаном; в ст. 34 - с Украиной). В конвенциях АР с КНР и Турцией подчеркивается принцип неприкосновенности консульской вализы и официальной корреспонденции консульского учреждения.

Все рассматриваемые конвенции содержат статью об освобождении консульских помещений от налогов и сборов, что означает наличие налогового (фискального) иммунитета у консульского учреждения (ст. 15 конвенций АР с РФ, Узбекистаном, Грузией, Туркменистаном и др.; ст. 38 - с КНР и ст. 40 - с Украиной). Вместе с тем в большинстве конвенций подчеркивается, что указанное освобождение консульства от налогов и сборов не распространяется на сборы, которые «представляют собой плату за конкретные виды обслуживания». Эти положения двусторонних конвенций полностью отвечают ст. 32 Венской конвенции 1963 г.

К числу консульских иммунитетов относится право представляемого государства пользоваться своим государственным флагом и гербом в государстве пребывания. Государственный флаг представляемого государства может быть вывешен и его государственный герб укреплен на здании, занимаемом консульским учреждением, на его входных дверях, а также на резиденции главы консульского учреждения и, когда это связано с исполнением служебных обязанностей, на его средствах передвижения. При этом должны соблюдаться законы, правила и обычаи государства пребывания (ст. 12 конвенций, ст. 29 Венской конвенции 1963 г.).

Привилегии и иммунитеты консульских должностных лиц. Одним из основополагающих принципов в области личных консульских привилегий и иммунитетов является норма, в силу которой, как предусматривает Венская конвенция о консульских сношениях 1963 г., и личная неприкосновенность, и иммунитет консульских лиц от юрисдикции государства пребывания гарантируется им не во всех случаях, а лишь тогда, когда совершаемые ими действия не выходят за рамки служебной необходимости, их официальных, признанных международным правом функций. Такой сугубо функциональный подход является главным отличительным признаком консульских привилегий и иммунитетов по сравнению с дипломатическими. 
С точки зрения современного консульского права, и прежде всего Венской конвенции о консульских сношениях 1963 г., именно в вопросе о личных привилегиях и иммунитетах консулов наблюдаются наибольшие различия по сравнению с привилегиями и иммунитетами дипломатов. Это касается главным образом двух основных видов иммунитетов личной неприкосновенности и иммунитета от юрисдикции.

С другой стороны, в двусторонних консульских конвенциях последнего времени личная неприкосновенность и иммунитет консульских должностных лиц от юрисдикции государства пребывания весьма часто практически совпадают с положением в этом отношении дипломатических агентов.

Главным иммунитетом консульских должностных лиц, как и дипломатических агентов, является личная неприкосновенность. Этот важный иммунитет направлен на обеспечение возможности беспрепятственного осушествления консульскими должностными лицами своих функций.

Венская конвенция о консульских сношениях 1963 г. следующим образом формулирует эту общую норму современного консульского права в ст. 41: «1) Консульские должностные лица не подлежат ни аресту, ни предварительному заключению иначе как на основании постановлений компетентных судебных властей в случае совершения тяжких преступлений. 2) За исключением случаев, указанных в п. 1 настоящей статьи, консульские должностные лица не могут быть заключены в тюрьму и не подлежат никаким другим формам ограничения личной свободы иначе как во исполнение судебных постановлений, вступивших в законную силу».

Приведенная выше норма отражает традиционный подход к вопросу о личной неприкосновенности консулов. Однако в консульских двусторонних конвенциях последнего времени встречаются и иные, достаточно разнообразные решения этого вопроса, направленные в целом на приближение консульской личной неприкосновенности к дипломатической неприкосновенности. Примером этому могут служить положения консульских конвенций АР о личной неприкосновенности консульских должностных лиц.

В частности, конвенции АР с Россией, Узбекистаном, Грузией, Туркменистаном, Казахстаном в ст. 18 указывают, что «1) Консульские должностные лица и члены их семей пользуются личной неприкосновенностью. Они не подлежат аресту или задержанию 
в какой бы то ни было форме. 2) Государство пребывания обязано относиться к консульским должностным лицам и членам их семей с должным уважением и принимать все необходимые меры для предупреждения каких-либо посягательств на их личную свободу и достоинство». Аналогичные положения содержатся в конвенциях АР с Украиной (ст. 36) и КНР (ст. 34).

Таким образом, приведенные положения вышеназванных конвенций полностью совпадают с содержанием ст. 29 Венской конвенции о дипломатических сношениях 1961 г., в которой говорится: «Личность дипломатического агента неприкосновенна. Он не подлежит аресту или задержанию в какой бы то ни было форме. Государство пребывания обязано относиться к нему с должным уважением и принимать все надлежащие меры для предупреждения каких-либо посягательств на его личность, свободу или достоинство». Из этого следует, что в данном случае консульский и дипломатический иммунитеты идентичны.

Консульские конвенции АР с Пакистаном и Турцией в ст. 19, по сушеству, воспроизводят норму, зафиксированную в ст. 41 Венской конвенции 1963 г.

Иммунитет от юрисдикции. При определении объема и характера прйвилегий и иммунитетов консульских должностных лиц Венская конвенция руководствуется функциональным критерием. В соответствии с этим критерием, зафиксированным в ст. 43 Венской конвенции 1963 г.: «1) Консульские должностные лица и консульские служащие не подлежат юрисдикции судебных и административных органов государства пребывания в отношении действий, совершаемых ими при выполнении консульских функций. 2) Однако положения п. 1 настоящей статьи не применяются в отношении гражданского иска:

а) вытекающего из договора, заключенного консульским должностным лицом или консульским служащим, по которому они прямо или косвенно не приняли на себя обязательств в качестве агента представляемого государства; либо

b) третьей стороны за вред, причиненный несчастным случаем в государстве пребывания, вызванным дорожным транспортным средством, судном или самолетом».

Договорная практика Азербайджанской Республики развивается как в отношении личной неприкосновенности, так и иммунитетов консульских должностных лиц, в направлении приближения и приравнивания их правового статуса к положению дипломатических агентов. 
Консульские конвенции АР с РФ, Узбекистаном, Грузией, Туркменистаном, Казахстаном в ст. 19 «Иммунитет от юрисдикции» отмечают: «Консульские должностные лица и члены их семей пользуются иммунитетом от уголовной, гражданской и административной юрисдикции в государстве пребывания, кроме следующих гражданских исков:

1) вытекающих из договоров, заключенных консульскими должностными лицами, по которым они прямо или косвенно не приняли на себя обязательств в качестве агента представляемого государства;

2) третьей стороны за ущерб, причиненный несчастным случаем, вызванным дорожным транспортным средством, судном или самолетом».

Консульская конвенция АР с КНР в ст. 35 дословно воспроизводит ч. 1 cr. 19 и называет в виде исключения пять (вместо двух) гражданских исков. В конвенции АР с Украиной ст. 37 «Иммунитет от юрисдикции» сформулирована следуюшим образом: «1) Консульские должностные лица пользуются дипломатическими привилегиями и иммунитетами в полном объеме, как дипломатические агенты, в соответствии с положениями Венской конвенции о дипломатических сношениях от 18 апреля 1961 года».

Таким образом, можно констатировать, что в вышеприведенных конвенциях АР иммунитет от юрисдикции государства пребывания консульских должностных лиц практически совпадает с иммунитетом от юрисдикции дипломатических агентов, предусмотренным ст. 31 Венской конвенции о дипломатических сношениях 1961 г.

Положения конвенций АР с Пакистаном и Турцией (ст. 20) об иммунитете консульских должностных лиц от юрисдикции государства пребывания полностью воспроизводят ст. 43 Венской конвенции о консульских сношениях 1963 г. «Освобождение от налогов и таможенных пошлин». Все рассматриваемые конвенции, как и Венская конвенция 1963 г., освобождают консульских должностных лиц и членов их семей, проживаюших вместе с ними, от всех государственных налогов, сборов и отчислений. Однако из этого делается исключение в отношении косвенных налогов и сборов на частное недвижимое имушество, находящееся на территории государства пребывания, налогов и сборов на частный доход, источник которого находится на территории государства пребывания, и в некоторых других случаях.

Консульские должностные лица и консульские сотрудники освобождаются от таможенных пошлин, налогов и сборов на предметы лично- 
го пользования, входящие в личный багаж, при передвижении за границу или предметы обстановки и мебель. По общему правилу личный багаж консульского должностного лица, следующий вместе с ним, освобождается от досмотра.

Действие привилегий и иммунитетов консульских должностных лиц начинается с момента их вступления на территорию государства пребывания и прекращается в момент, когда они оставляют эту страну.

Консульские функции. В принципе, все консульские функции, закрепленные в консульских конвенциях АР, сформулированы на основании положений ст. 5 Венской конвенции о консульских сношениях 1963 г. с учетом специфики двусторонних отношений.

Следует напомнить, что в соответствии со ст. 5 основными консульскими функциями являются:

а) защита в государстве пребывания интересов представляемого государства и граждан (физических и юридических лиц) в пределах, допускаемых международным правом;

b) содействие развитию торговых, экономических, культурных и научных связей между представляемым государством и государством пребывания, а также содействие развитию дружественных отношений между ними иными путями в соответствии с положениями настоящей Конвеннци;

c) выяснение всеми законными путями условий и событий в торговой, экономической, культурной и научной жизни государства пребывания, сообшение о них правительству представляемого государства и представление сведений заинтересованным лицам;

d) выдача паспортов и проездных документов гражданам представляемого государства и виз или соответствующих документов лицам, желаюшим поехать в представляемое государство;

е) оказание помощи и содействия гражданам (физическим и юридическим лицам) представляемого государства.

Далее идут функции консула в области нотариата, регистрации актов гражданского состояния, консульской легализации, охраны интересов несовершеннолетних или лиц, не обладающих полной дееспособностью, по представительству своих граждан в судебных или иных учреждениях государства пребывания, охраны и ликвидации наследства и др.

Положения статей консульских конвенций АР с иностранными государствами о консульских функциях в своей основе совпадают с содержанием ст. 5 «Консульские функции» Венской конвенции о кон- 
сульских сношениях 1963 г. Некоторые конвенции воспроизводят ст. 5 полностью (иногда с небольшими дополнениями и разъяснениями), другие, перечислив основные функции, достаточно подробно конкретизируют или детализируют ее пункты постатейно.

Рамки настоящей статьи не позволяют подробно проанализировать консульские функции каждой рассматриваемой конвенции, по-видимому, в этом нет и особой необходимости, поскольку данные вопросы достаточно полно отражены в учебниках и учебных пособиях по курсам «консульское право» и «консульская служба».

Анализ консульских конвенций, заключенных Азербайджанской Республикой с иностранными государствами, позволяет сделать определенные выводы.

1. Консульские конвенции заключены в целях дальнейшего развития и урегулирования консульских отношений, состояние которых в целом соответствует общему состоянию межгосударственных отношений. Конвенции призваны, как подчеркивается в их преамбулах, содействовать укреплению принципов развития дружественных отношений и сотрудничества между государствами, а также более эффективной защите прав и интересов своих граждан. Они предусматривают и создают благоприятные условия для учреждения и деятельности консульских представительств на взаимной основе.

2. Основными консульскими функциями являются защита прав и интересов представляемого государства, его граждан и юридических лиц, а также содействие развитию торговых, экономических, культурных и научных связей между представляемым государством и государством пребывания. При этом при отправлении своих функций консул получает поддержку государства пребывания. Это является одной из особенностей консульских конвенций и договорной практики Азербайджанской Республики.

3. Для выполнения его функций консулу обеспечивается свобода служебной деятельности в рамках двусторонних консульских конвенций и внутреннего законодательства государства пребывания, предоставляются иммунитеты и привилегии. Эти иммунитеты и привилегии определяются функциями консула: они несколько меньше, чем у-дипломатов, но в данных конвенциях они максимально приближены к дипломатическим, а в большинстве конвенций они совпадают (конвенции АР с Республикой Узбекистан, Российской Федерацией, Грузией, Туркменистаном, Казахстаном, КНР, Украиной). 
4. При заключении двусторонних консульских конвенций с зарубежными государствами Азербайджанская Республика руководствовалась положениями Венской конвенции о консульских сношениях 1963 г., проявляя при этом особенности своей договорной политики и практики. В отличие от Венской конвенции, в двусторонних конвенциях подробно разъясняется порядок назначения и допущения глав консульских учреждений, более четко определено гражданство консульских должностных лиц, исключена т.н. «пожарная оговорка», не упоминается о праве государства пребывания регулировать численность консульского персонала и т.п.

5. Исходя из сложившегося опыта международно-правовой практики, Азербайджанская Республика в ходе внешнеполитических переговоров стремится к принятию пакета документов, охватывающих все основные аспекты двустороннего сотрудничества. Это прежде всего договоры о принципах межгосударственных отношений, о поощрении и взаимной защите инвестиций, об избежании двойного налогообложения, о правовой помощи, а также договоры в области консульских сношений и в области культурного и гуманитарного сотрудничества.

Двусторонние консульские конвенции являются, на наш взгляд, приоритетными среди перечисленных договоров. Это обуславливается тем, что нормальные политические, экономические, научные и гуманитарные отношения не могут развиваться без соответствующего консульского обеспечения. 